\title{
日本人若年女性における体脂肪の増減の部位差
}

\author{
弓桁 亮介 $^{1} \quad$ 角田 直也 $^{2} \quad$ 堀川 浩之 $^{1}$
}

\section{The part difference of change of body fat in Japanese young women.}

\author{
Ryosuke YUMIGETA ${ }^{1}$, Naoya TSUNODA ${ }^{2}$ and Hiroyuki HORIKAWA ${ }^{1}$
}

The purpose of this study was to clarify the part difference of change of body fat in Japanese young women. Subjects were 142 healthy female university students who were living in a dormitory. In particular, 21 subjects who showed the remarkable increased percentage of total body fat were grouped as the increase group. 24 subjects who showed the remarkable decreased percentage of total body fat were grouped as the decrease group. Body weight, total and regional body fat and muscle volume were measured by bioelectrical impedance analysis method. Each item was measured for two times in June and December.

The difference of change in the percentage of body fat of a trunk showed the highest value in parts of the body. The difference of change in the percentage of body fat of an arm was higher than that of a leg.

From these results, the part difference existed to a change of the body fat. It was suggested that the part in which body fat tends to increase is the part in which it tends to decreases.

Key words : Japanese young women, total body fat, regional body fat 日本人若年女性，全身体脂肪，部位別体脂肪

\section{I 緒言}

体脂肪は生活習慣病と密接な関係があり，健康 的な身体を維持する上で最も重要な要因の 1 つで あることはよく知られている。近年, 日本の若年 女性は瘦身願望が強い傾向にあり, 食事制限だけ に頼った無理なダイエットにより瘦せているのに 筋肉量が少なく, 体脂肪率が高い隠れ肥満が問題 視されている1).

これまでに，ヒトの体脂肪の性差については, 思春期前の男女の身体組成の比較から，思春期以
前から女性の方が体脂肪量が多いこと齐や，成人 期以降の男女の皮下脂肪厚の比較から, 身体のす べての部位において, 女性が男性より有意に高值 を示すことが報告されている3)。これらのことか ら，一般的に男性は筋肉質でがっちりした体型で あるのに対して, 女性は体脂肪が多く, 思春期以 降に丸みを帯びた体型になると言われている。さ らに，女性の体脂肪分布についても検討がなされ ている。湯浅他 ${ }^{4}$ は，超音波法を用いて女性の体 幹と体肢の皮下脂肪分布について検討し，身体の 末梢部よりも腹部, 腰部, 大腿部などに皮下脂肪

\footnotetext{
1 昭和大学富士吉田教育部

2 国土舘大学大学院スポーツ・システム研究科

${ }^{1}$ Faculty of Arts and Sciences at Fujiyoshida, Showa University

${ }^{2}$ Graduate School of Sport System, Kokushikan University
} 
が多く沈着することを明らかにしている。また， 女性は慰部や大腿部といった部位に脂肪が蓄積し やすい下半身蓄積型の分布を示す傾向が強いとい う指摘もある ${ }^{3)}$ 。これらのことから，女性におい ては, 腹部, 腰部及び慰部といった体幹部と大腿 部といつた脚部に体脂肪が蓄積しやすいものと考 えられる。

一方, 著者らは寮生活をしている女子大学生を 対象として, 身体組成の変化について検討を重ね てきた。例えば, 入寮時と退寮時の身体組成を比 較した結果 ${ }^{5-7)}$, 入寮時より退寮時の方が体重及 び体脂肪量が有意に増加することを明らかにして きた。これらの結果を踏まえ，およそ 9 ケ月間の 寮生活において, どの時期に身体組成が変化して いるのかを明らかにするために, 毎月 1 回の身体 組成の測定を行い, 女子大学生の身体組成の月別 変化の検討を試みた。その結果, 体重及び全身体 脂肪量が 6 月に最も低值を示し, 12 月に最も高值 を示す傾向がみられ, 夏から冬にかけて徐々に体 重及び全身の体脂肪量が増加していくことが明ら かになった ${ }^{8)}$ 。しかしながら, 全身体脂肪量が最 も低值を示した 6 月と最も高值を示した 12 月を比 較した場合, 身体のどの部位の体脂肪が増加し, 体脂肪の分布がどのように変化したのかについて は明らかになっておらず，不明のままである。

これまでの体脂肪分布に関する研究3,9-11)では, 一般的な女性や肥満者と瘦身者を対象として, 超 音波法により身体各部の皮下脂肪厚を測定し, 比 較することにより体脂肪の増加しやすい部位を横 断的に明らかにしているものがほとんどである. 一方, 同一の被検者を対象として, 一定期間の運 動介入後に身体各部の体脂肪にどのような変化が 生じたのかを検討した研究 ${ }^{12,13)}$ は散見される。し かしながら,これらの研究は高齢な男女及び男性 を対象に, キャリパー法を用いて皮下脂肪厚から 体脂肪の減少した部位を明らかにしたものであ

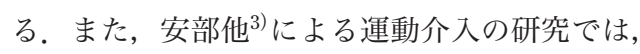
若年女性 1 名を対象としたものであり, 若年女性 における身体部位別の体脂肪の減少やその部位差 については十分な知見は得られていない。した
がって，比較的簡便に体脂肪を計測できるイン ピーダンス法を用いて, 若年女性の全身の体脂肪 の著しい変化を身体部位別に増加と減少の両面か ら縦断的に検討することや，体脂肪の増減の部位 差を明らかにすることは意義深いと考えられる。

そこで本研究では, 同一の生活環境の女子大学 生を対象に, 全身及び身体各部の体脂肪の変化を 縦断的に検討するとともに, 体脂肪の増減の部位 差を明らかにすることを目的とした。

\section{II 方法}

\section{1. 被検者}

被検者は, 寮生活を送る女子大学生 142 名とし た。 また，本研究では全被検者における 6 月と 12 月の全身体脂肪率の差の平均値 +1 標準偏差によ り, 全身体脂肪率に顕著な増加がみられた 21 名を 増加群, 全身体脂肪率の差の平均值 -1 標準偏差 により, 全身体脂肪率に顕著な減少がみられた 24 名を減少群として抽出し, 体脂肪の増減の部位差 を分析する際の対象とした。表 1 に 6 月の測定時 における被検者の年齢及び身体的特性を示した。 被検者にはあらかじめ研究の目的, 方法及び実験 における安全性を説明し, 書面によって実験への 参加の同意を得た。本研究は, 昭和大学富士吉田 教育部倫理委員会の承認を得て実施した。

\section{2. 身体組成の測定}

体重, 全身体脂肪量, 全身体脂肪率, 身体部位 別の体脂肪率及び全身筋肉量の測定には, 体組成 計（BC-621，TANITA 社製）を用いた。なお，身 体部位別の体脂肪の測定は, 上腕部, 前腕部及び 手部を合わせた腕部，大腿部，下腿部及び足部を 合わせた脚部, 胴体である体幹部の 3 部位とし， 腕部及び脚部については左右の值の平均值をそれ ぞれの部位の值として採用した。測定は先行研究 の結果 ${ }^{8)}$ から, 全身体脂肪量が最も低いと考元ら れる 6 月と最も高いと考えられる 12 月に実施し た。なお，インピーダンス法による測定誤差をで きるだけ少なくするために, 先行研究 ${ }^{14)}$ に準拠 し, 被検者には起床後すぐに排尿のみを済ませた 
表 1 被検者の年齢及び身体的特性

\begin{tabular}{|c|c|c|c|c|c|}
\hline & \multirow{2}{*}{$\mathrm{n}$} & 年齢 & 身長 & 体重 & BMI \\
\hline & & (yrs) & $(\mathrm{cm})$ & $(\mathrm{kg})$ & $\left(\mathrm{kg} / \mathrm{m}^{2}\right)$ \\
\hline 全被検者 & 142 & $18.3 \pm 0.6$ & $159.0 \pm 5.0$ & $53.7 \pm 6.7$ & $21.2 \pm 2.1$ \\
\hline 増加群 & 21 & $18.2 \pm 0.6$ & $159.4 \pm 4.8$ & $52.9 \pm 8.4$ & $20.7 \pm 2.4$ \\
\hline 減少群 & 24 & $18.5 \pm 0.7$ & $159.0 \pm 5.2$ & $54.8 \pm 4.9$ & $21.7 \pm 2.0$ \\
\hline
\end{tabular}

平均值士標準偏差

後に測定をした。また，測定時の着衣は，Tシャ ツとジャージに統一した。立位姿勢でのインピー ダンス法を用いた全身及び部位別の体脂肪率の測 定精度については, DXA法との測定値の間におい て高い相関関係（全身: $\mathrm{r}=0.88, \mathrm{p}<0.05$, 腕部 : $\mathrm{r}=0.75, \mathrm{p}<0.05$, 脚部 $: \mathrm{r}=0.61, \mathrm{p}<0.05$, 体幹 部 $: \mathrm{r}=0.82, \mathrm{p}<0.05 ）$ がみられている ${ }^{15)}$.このこ とから, 本研究における立位姿勢でのインピーダ ンス法による全身及び部位別の体脂肪率の測定精 度は, 高いものであると判断した。

\section{3. 身体各部の体脂肪率の増加及び減少の差の 算出}

身体各部における体脂肪率の差については，12 月の測定值から 6 月の測定值を引くことにより算 出し, 増加群においては増加の差, 減少群におい ては減少の差と定義した。

\section{4. 統計処理}

6 月及び 12 月の体重，全身体脂肪量，全身体脂 肪率, 全身筋肉量, 部位別の体脂肪率の平均值の 差の検定には，対応のある t-testを用いた。また， 増加群及び減少群における体脂肪率の増加及び減 少の差の部位間比較には，対応のある一元配置の 分散分析を用いた。要因に有意な主効果が認めら れた場合には，ホルムの多重比較を用いて有意性 の検定を行った。いずれも有意水準は $5 \%$ 未満と した。また,これらの統計処理には, R. version3.0.0を用いた。

\section{III 結果}

\section{1. 全被検者における身体組成の変化}

表 2 に全被検者における 6 月と 12 月の体重, 全身体脂肪量，全身体脂肪率及び全身筋肉量の変 化を示した。体重，全身体脂肪量及び全身体脂肪 率において，6月より 12 月の方が高值を示し，有 意な増加がみられた。一方，全身筋肉量において は，ほぼ同様の值を示し，有意な増加はみられな かった。

\section{2. 全被検者における体脂肪率の部位別変化}

表 3 に全被検者における体脂肪率の部位別変化 を示した，腕部，脚部及び体幹部のすべての部位 に掞いて，6月より 12 月の方が高值を示し，有意 な増加がみられた。

\section{3. 増加群及び減少群における身体組成の変化} 表 4 は増加群及び減少群における 6 月と 12 月 の身体組成の変化を示したものである，増加群で は体重, 全身体脂肪量, 全身体脂肪率において, 6 月より 12 月の方が高值を示し, 有意な増加がみ られた。一方，減少群では体重，全身体脂肪量及 び全身体脂肪率において，6月より 12 月の方が低 值を示し，有意な減少がみられた。しかしながら， 全身筋肉量においては，両群とも有意な変化はみ られなかった。

\section{4. 増加群及び減少群における体脂肪率の部位 別変化}

表 5 に増加群及び減少群における体脂肪率の部 位別変化を示した。増加群では腕部，脚部及び体 
表 2 全被検者における身体組成の変化

\begin{tabular}{lccc}
\hline & 6 月 & 12 月 & \\
\hline 体重 $(\mathrm{kg})$ & $53.7 \pm 6.7$ & $54.7 \pm 7.1$ & $* *$ \\
全身体脂肪量 $(\mathrm{kg})$ & $14.8 \pm 4.0$ & $15.7 \pm 4.3$ & $* *$ \\
全身体脂肪率 $(\%)$ & $27.1 \pm 4.2$ & $28.2 \pm 4.1$ & $* *$ \\
全身筋肉量 $(\mathrm{kg})$ & $36.7 \pm 3.1$ & $36.8 \pm 3.1$ & N. S. \\
\hline 対応のある t-test $(* *$ & $: \mathrm{p}<0.01)$ & 平均值士標準偏差
\end{tabular}

表 3 全被検者における体脂肪率の部位別変化

\begin{tabular}{cccc}
\hline & \multicolumn{4}{c}{6 月 } & 12 月 & \\
\hline 腕 部 $(\%)$ & $26.7 \pm 4.2$ & $27.7 \pm 4.1$ & $* *$ \\
脚 部 $(\%)$ & $32.1 \pm 2.8$ & $33.0 \pm 2.7$ & $* *$ \\
体幹部 $(\%)$ & $24.0 \pm 5.5$ & $25.5 \pm 5.4$ & $* *$ \\
\hline 対応のある $\mathrm{t}$-test $(* *: \mathrm{p}<0.01)$ & 平均值士標準偏差
\end{tabular}

表 4 増加群及び減少群における身体組成の変化

\begin{tabular}{|c|c|c|c|c|c|c|}
\hline & \multicolumn{3}{|c|}{ 増加群 } & \multicolumn{3}{|c|}{ 減少群 } \\
\hline & 6 月 & 12 月 & & 6 月 & 12 月 & \\
\hline 体重（kg） & $\begin{array}{c}52.9 \pm 8.4 \\
(41.7-80.5)\end{array}$ & $\begin{array}{c}56.3 \pm 9.4 \\
(42.2-87.4)\end{array}$ & $* *$ & $\begin{array}{c}54.8 \pm 4.9 \\
(47.2-64.3)\end{array}$ & $\begin{array}{c}54.0 \pm 5.1 \\
(47.2-64.4)\end{array}$ & $* *$ \\
\hline 全身体脂肪量（kg） & $\begin{array}{l}13.9 \pm 5.1 \\
(8.7-31.5)\end{array}$ & $\begin{array}{c}17.0 \pm 5.8 \\
(10.2-36.8)\end{array}$ & $* *$ & $\begin{array}{c}15.9 \pm 3.6 \\
(10.2-24.6)\end{array}$ & $\begin{array}{l}14.9 \pm 3.6 \\
(9.5-23.8)\end{array}$ & $* *$ \\
\hline 全身体脂肪率（\%) & $\begin{array}{c}25.6 \pm 4.8 \\
(17.7-39.2)\end{array}$ & $\begin{array}{c}29.5 \pm 4.7 \\
(23.0-42.1)\end{array}$ & $* *$ & $\begin{array}{c}28.7 \pm 4.6 \\
(21.0-38.2)\end{array}$ & $\begin{array}{c}27.4 \pm 4.6 \\
(19.9-37.3)\end{array}$ & $* *$ \\
\hline 全身筋肉量（kg） & $\begin{array}{c}36.8 \pm 3.4 \\
(31.1-45.8)\end{array}$ & $\begin{array}{c}37.1 \pm 3.7 \\
(30.3-47.4)\end{array}$ & N.S. & $\begin{array}{c}36.7 \pm 2.5 \\
(33.2-42.8)\end{array}$ & $\begin{array}{c}36.8 \pm 2.5 \\
(32.5-42.5)\end{array}$ & N.S. \\
\hline
\end{tabular}

表 5 増加群及び減少群における体脂肪率の部位別変化

\begin{tabular}{|c|c|c|c|c|c|c|}
\hline & \multicolumn{3}{|c|}{ 増加群 } & \multicolumn{3}{|c|}{ 減少群 } \\
\hline & 6 月 & 12 月 & & 6 月 & 12 月 & \\
\hline 腕 部 (\%) & $25.3 \pm 4.9$ & $28.5 \pm 4.9$ & $* *$ & $28.1 \pm 4.0$ & $27.1 \pm 4.3$ & $* *$ \\
\hline 脚 部 (\%) & $31.0 \pm 3.3$ & $33.4 \pm 3.1$ & $* *$ & $32.8 \pm 2.8$ & $32.6 \pm 2.9$ & N.S. \\
\hline 体幹部（\%） & $22.1 \pm 6.1$ & $26.9 \pm 6.0$ & $* *$ & $26.3 \pm 6.2$ & $24.1 \pm 6.1$ & $* *$ \\
\hline
\end{tabular}

幹部のすべての部位において，6月より 12 月の方 が高值を示し, 有意な増加がみられた。一方, 減 少群では腕部及び体幹部において，6月より 12 月 の方が低值を示し，有意な減少がみられた。しか し，脚部においてはほぼ同様の值を示し，有意な 減少はみられなかった。

\section{5. 増加群における体脂肪率の増加の差の部位 間比較}

図 1 は増加群における体脂肪率の増加の差の部 位間比較を示したものである。体幹部が最も高值 を示し，腕部及び脚部との間に有意な差異が認め
られた。また，腕部と脚部との間にも有意な差異 が認められた。

\section{6. 減少群における体脂肪率の減少の差の部位 間比較}

図 2 は減少群における体脂肪率の減少の差の部 位間比較を示したものである。体幹部が最も高值 を示し, 腕部及び脚部との間に有意な差異が認め られた。また，腕部と脚部との間にも有意な差異 が認められた。 


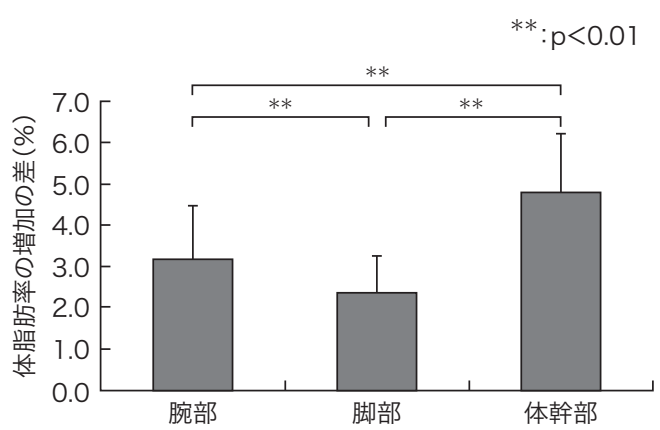

図 1 増加群における体脂肪率の増加の差の部位間 比較

・対応のある一元配置分散分析及びホルムの多重比 較検定

\section{$\mathrm{I}$ 考察}

\section{1. 全被検者における身体組成の変化}

全被検者における 6 月と 12 月の身体組成を比較 した結果，体重，全身体脂肪量及び全身体脂肪率 において, 有意に増加する傾向がみられた。一方, 全身筋肉量においては，全被検者では有意な変化 がみられなかった。これらの結果は，これまでの 先行研究の結果 ${ }^{5-7)}$ とほぼ一致するものであった。 つまり, 全被検者の体重の増加は体脂肪量の増加 によってもたらされたことを意味している。皮下 脂肪が冬季に増大し夏季に減少することは，気候 の変動に対して体温調節機能がより合理的に対応 するためには合目的 ${ }^{16)}$ という指摘があるように， 体脂肪は寒さから身を守るための断熱材としての 役割があり，季節差 ${ }^{17)}$ がみられる。

また，大学生の運動習慣について，藤原他 ${ }^{18)}$ は 北陸地区の大学生を対象に秋季と冬季の日常生活 の運動の質と量の検討から, 秋季に比べ冬季に運 動量の減少がみられ, 男女ともに体脂肪率が増加 し，除脂肪量が減少したことを報告している。本 研究においても, 被検者が寮生活をする地域は標 高約 $900 \mathrm{~m}$ にあり, 秋季から冬季にかけて気温は 急激に低下し，夜には氷点下になることも珍しく ない.したがって, 冬季に運動量が減少してもお かしくない環境にあると考えられる。しかしなが

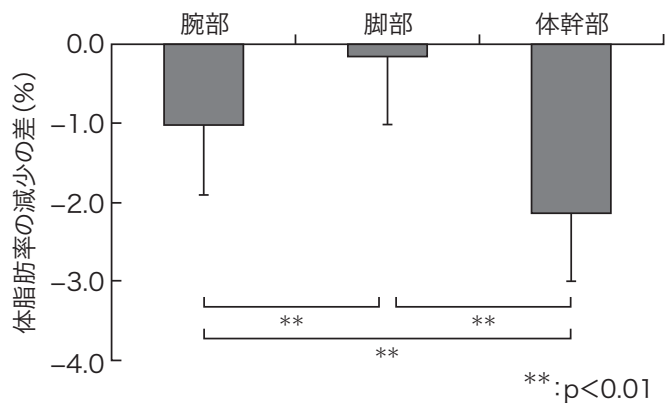

図 2 減少群における体脂肪率の減少の差の部位間比 較

・対応のある一元配置分散分析及びホルムの多重比較 検定

ら，本研究において全身筋肉量は有意な変化をみ せていない.これまでの先行研究では, 除脂肪量 が増加するとの結果 ${ }^{5,6)}$ や, 逆に減少するという結 果7)もあり，一致した結果が得られていない.

\section{2. 増加群及び減少群における体脂肪の部位別} 変化及び部位間差

増加群の 6 月と 12 月の体脂肪率を部位別に比較 した結果，すべての部位で有意に増加する傾向が みられた。 また, 身体各部の体脂肪率の増加の差 を部位間で比較した結果，体幹部が最も高值を示 し, 腕部及び脚部との間に有意な差異がみられ た。さらに，腕部と脚部の間にも有意な差異がみ られた。これらをまとめると, 全身の体脂肪の増 加は, 身体のすべての部位の体脂肪が増加するこ とによって生じているものの, その増加は体幹部 が最も多く, 次に腕部, 最後に脚部という部位差 がみられることを意味している，体脂肪の蓄積に ついて, 安部他 ${ }^{3)}$ は肥満者と瘦身者の皮下脂肪量 の比較から，皮下脂肪が局所的にある部位に集中 して蓄積することはありえないと報告しており， 本研究の結果はこの報告と一致するものである. したがって, 全身の体脂肪の増加は, 身体のすべ ての部位に体脂肪が蓄積することによってもたら され, 体脂肪が全く蓄積しない部位は存在しない と考えられる。 
一方，超音波法を用いて皮下脂肪厚から皮下脂 肪分布を検討した湯浅他 ${ }^{4)}$ は, 推定総皮下脂肪厚 と皮下脂肪厚の回帰式の勾配が部位によって異な ることから, 総皮下脂肪量の増加にともなう皮下 脂肪沈着には部位差があり, 腹部が顕著であるこ とを示している．また，体脂肪の増加の部位差に ついては, 体脂肪が体幹部へ付着しやすいこと帛) が指摘されている. 本研究においても, 体幹部の 体脂肪率の増加は腕部及び脚部に比べ有意に高值 を示しており,これらの指摘と一致した。した がって, 体幹部が体脂肪の最も増加しやすい部位 であると考えられる。 さらに, 本研究では腕部の 方が脚部に比べ有意に高い体脂肪率の増加を示し た. Murakami et al. ${ }^{20)}$ は, 体脂肪の蓄積の仕方は 3 つに分類され, その 1 つに体幹と上腕に蓄積し やすいパターンがあることを示している，本研究 では上腕部, 前腕部及び手部をまとめて腕部とし ているため, 上腕部に限定した比較はできないも のの, 腕部も体脂肪が蓄積しやすい部位の 1 つで あると推察される。

一方, 減少群の 6 月と 12 月の体脂肪率を身体部 位別に比較した結果, 腕部及び体幹部では有意な 減少がみられたものの, 脚部では有意な減少がみ られなかった。また, 身体各部の体脂肪率の減少 の差を部位間で比較した結果, 体幹部が腕部及び 脚部に比べて有意に減少し, 腕部も脚部に比べて 有意に減少していた。これらの結果から, 体脂肪 の減少においても体幹部が最も高く, 次に腕部, 最後に脚部という部位差が存在することになる. 安部他 ${ }^{3)}$ は, 若年女性を対象に 3 ケ月間のトレー ニングにより体脂肪率が低下した際の皮下脂肪の 変化を検討した結果, 低下率が最も大きかった部 位は体幹であり, 大腿部や下腿部での低下率は非 常に小さなものであったことを報告している. Després et al. ${ }^{13)}$ も，20 週間のトレーニングにより 全身脂肪量が著しい減少を示した際の体幹と体肢 の皮下脂肪厚の比較から, 体肢より体幹の方が減 少率が大きく, 皮下脂肪の減少には部位差がある ことを指摘しており, 本研究の結果はこれらの報 告と一致するものである。したがつて, 体脂肪の
減少にも部位差がみられ，体幹部の体脂肪が最も 減少しやすい部位であると考えられる.

また, 減少群の脚部の体脂肪率は減少傾向を示 すものの, 有意な減少はみられなかった。局所の 体脂肪の減少について, 北川 $\left.{ }^{2}\right)$ 局所の筋運動へ のエネルギーがその表在する皮下脂肪より供給さ れるような, 生理学的なエネルギー供給経路は考 えられないとの見解を示している。 三浦他 ${ }^{21)} も ，$ 片脚の有酸素性脚自転車トレーニングによる運動 部位の皮下脂肪の減少について検討し, トレーニ ング脚の皮下脂肪が選択的に減少しないことを明 らかにしている。本研究においても, 減少群は全 身体脂肪率が減少しているにもかかわらず，日常 生活で最も使用する脚部の体脂肪率は有意に減少 する傾向を示していない. つまり，身体活動を 行った際に使用した部位の脂肪が，そのままエネ ルギー源として利用されないと考えられる。ま た, 本研究では体脂肪が増加傾向にある集団の中 から, 全身体脂肪率の差の平均值 -1 標準偏差に より減少群を設定した. 6 月から 12 月の全身体脂 肪率の変化を両群で比較した場合, 増加群が $3.9 \%$ 増加しているのに対して減少群は $1.3 \%$ の減 少であった。したがって, 減少群の体脂肪率の減 少が増加群の体脂肪率の増加と同程度であったな らば, 脚部においても有意な減少がみられる可能 性も考えられる。このことも, 滅少群の脚部の体 脂肪率が有意に減少しなかった 1 つの要因と推察 される。

本研究は体脂肪の変化を増加と減少の両面から 検討し, いずれも体幹部が最も大きく増減する傾 向を示した。体脂肪は皮下脂肪と内藏脂肪の 2 つ に分類されることが知られており, 本研究におけ る体幹部の体脂肪の増減が, 皮下脂肪と内臟脂肪 のどちらの影響を強く受けたものかは不明であ る.いずれにしても, 皮下脂肪と内藏脂肪の増減 については, 個人差が存在すること年积,23) が指摘 されており, 皮下脂肪と内臟脂肪の増減における 個人差については，今後さらに検討する必要があ ると考えられる。 


\section{$\mathrm{V}$ 結 論}

本研究では, 同一の生活環境の女子大学生を対 象に, 全身及び身体各部の体脂肪の変化を縦断的 に検討するとともに，体脂肪の増減の部位差を明 らかにすることを目的として分析を行なった結 果, 体脂肪の増減には部位差が存在し, 体幹の体 脂肪が最も増減することが明らかとなった。ま た, 体脂肪が増加しやすい部位は, 体脂肪が減少 しやすい部位であることが示唆された.

\section{謝辞}

本研究において, ご協力いただきました $\mathrm{S}$ 大学の女 子学生の皆様に心より感謝申し上げます.

\section{文献}

1）福永哲夫. 1 日 5 分！「座り」筋トレ; 超簡単「貯 金」運動のススメ。東京：講談社, $2009:$ 170-171.

2）北川薰. 身体組成とウエイトコントロール；子ど もからアスリートまで. 東京: 杏林書院, 1991 : 35-109.

3）安部孝，福永哲夫．日本人の体脂肪と筋肉分布. 東京: 杏林書院, $1995: 2-87$.

4）湯浅景元，後藤佐都美。日本人女子の体幹と体肢 における皮下脂肪の分布と総量. 体力科学, $1993 ; 42: 46-52$.

5）堀川浩之, 朝比奈茂, 佐藤三千雄. 本学学生にお ける身体組成変化の性差。昭和大学教養部紀要, $1998 ; 29: 69-73$.

6）弓桁亮介, 朝比奈茂, 堀川浩之. 本学学生におけ る 1 年間の体力変化. 昭和大学富士吉田教育部紀 要, $2008 ; 3: 33-39$.

7）弓桁亮介, 伊原佑樹, 青葉貴明, 他. 本学学生に おける 1 年間の体力変化; 第 2 報。昭和大学富士 吉田教育部紀要, $2010 ; 5: 65-70$.

8）弓桁亮介, 堀川浩之. 寮生活における女子学生の 身体組成の変化. 昭和大学富士吉田教育部紀要, $2011 ; 6: 37-41$.

9）矢ヶ崎信子，豊川裕之。日本人の皮下脂肪厚の記 述疫学的研究. 民族衛生, $1989 ; 55: 100-112$.

10）斎藤秀子, 田村照子. 成人女子の皮下脂肪分布に ついて; 第 2 報 四肢部皮下脂肪厚と全身の脂肪分 布型. Ann Physiol Anthropol, 1994 ；113：183-
196.

11）古泉一久. 筋厚, 皮下脂肪厚の分布と身体組成の 関係。城西大学研究年報自然科学編，1998；22： 125-133.

12) Sidney KH, Shephard RJ, Harrison JE. Endurance training and body compostition of the elderly. Am J Clin Nutr, $1977 ; 30: 326-333$

13) Després JP, Bouchard C, Tremblay A, et al. Effects of aerobic training on fat distribution in male subjects. Med Sci Sports Exerc, $1985 ; 17: 113-118$.

14）朝井均, 坂口守男, 川口小夜子, 他. 体脂肪率測 定における日内変動に関する研究。大阪教育大学 紀要第III部門， 2005；53 (2)：75-82.

15) Sato $S$, Demura S, Kitabayashi $T$, et al. Segmental body composition assessment for obese Japanese adults by single-frequency bioelectrical impedance analysis with 8-point contact electrodes. J Physiol Anthropol, $2007 ; 26: 533-540$.

16）石榑清司，大城順子，柴田純子，女子大学生の皮 下脂肪厚 ; 季節的変化並びに運動クラブ活動の影 響. 体力科学, $1980 ； 29: 205-212$.

17）山下静江, 井町和香, 武藤志真子. 体脂肪率の季 節変動とその性差および地域差。〈らしき作陽大 学・作陽短期大学研究紀要, $2005 ; 38(2): 51-$ 63.

18）藤原勝夫，外山寛，幸山彰一，他．冬季における 北陸地区大学生の身体活動と体力の変化. 金沢大 学教養部論集自然科学篇, $1990 ; 27: 9-23$.

19）宮崎滋. 大人のカラダ STYLE. 東京: 学研パブ リッシング, $2011:$ 8-9. $^{-}$.

20) Murakami M, Hikima R, Arai S, et al. Short-term longitudinal changes in subcutaneous fat distribution and body size among Japanese women in the third decade of life. Appl Human Sci, 1999 ; 18 : 141-149.

21）三浦朗，佐藤広徳，福場良之。局所トレーニング は運動部位の皮下脂肪を減少させるか？；片脚 の有酸素性脚自転車トレーニングがトレーニング 脚の脂肪断面積および酸素利用能に及ぼす影響. デサントスポーツ科学, $1999 ; 20: 106-115$.

22）勝川史憲. 介入試験からみた内臓脂肪の減少と代 謝指標の改善効果. 日本臨床スポーツ医学会誌, $2009 ; 17: 206-212$.

23）佐伯修, 副島愛, 木村歩, 他. 減量に伴う内臟 • 皮下脂肪の減少率における男女の違いについて。 J Rehabil Health Sci, 2009 ; 17 : 15-20. （受稿 2014.3.17；受理２014.10.10） 